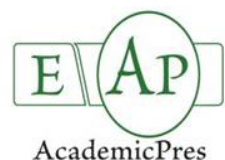

AcademicPres

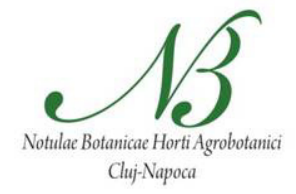

\title{
Potential of Second Crops of Oil Radish and White Mustard as Fall Grazing Pasture for German Mutton Merino Sheep
}

\author{
Péter PÓTI ${ }^{1 *}$, Ferenc PAJOR ${ }^{1}$, Ákos BODNÁR ${ }^{1}$, Károly PENKSZA², \\ János TŐZSÉR ${ }^{1}$, Csaba GYURICZA ${ }^{3}$ \\ ${ }^{1}$ Szent István University, Institute of Animal Husbandry, Páter Karoly 1, H-2100 Gödöllo', Hungary; poti.peter@mkk.szie.hu (*orresponding author) \\ ${ }^{2}$ Szent István University, Institute of Botany and Plant Physiology, Páter Karoly 1, H-2100 Gödöllo", Hungary \\ ${ }^{3}$ Szent István University, Institute of Crop Production, Páter Karoly 1, H-2100 Gödöllö, Hungary
}

\begin{abstract}
Second crops of oil radish (Raphanus sativus) and white mustard (Sinapis alba) being in the bloom stage were evaluated for nutritive value for wether lambs ( $\mathrm{n}=5$ per crop, $\mathrm{BW}=35.6 \mathrm{~kg}$ ) and in situ grazability by ewes $(\mathrm{n}=15$ per crop, $\mathrm{BW}=50 \mathrm{~kg})$. Animals received no supplemental feed. The two forage crops differed in dry matter (DM) (135 vs. $154 \mathrm{~g} / \mathrm{kg})$ as well as in crude protein (148 vs. $206 \mathrm{~g}$ ), crude fibre (141 vs. $194 \mathrm{~g}$ ) and N-free extract (550 vs. $482 \mathrm{~g}$ ) per kg DM. In the feeding trial, total daily DM intake of lambs from oil radish and white mustard differed (1063 vs. $1203 \mathrm{~g} / \mathrm{head}$ ) but was similar in percent bodyweight (3.3-3\%). Apparent digestibility of the two forage crops were similar for crude protein $(69-70 \%)$ and $\mathrm{N}$-free extract $(70-71 \%)$, but differed $(\mathrm{P}<0.001)$ for crude fibre (63 vs. $54 \%)$; the values were similar for TDN (61.6-62.9\%), DE (11.36-11.61 MJ), $\mathrm{ME}(9.32-9.52 \mathrm{MJ})$ and $\mathrm{NE}_{\mathrm{m}}(5.70-5.88 \mathrm{MJ})$ per $\mathrm{kg} \mathrm{DM}$. In the 4-day grazing trial was used rotational grazing, based on results, the oil radish provided a carrying capacity twice as high as white mustard's notably, 1700 vs. 740 ewe grazing days per ha - equal to 60 ewes grazing one hectare for 28 and 12 days, respectively. Thus, oil radish seemed better to be used as fall grazing pasture for mutton sheep.
\end{abstract}

Keywords: oil radish, white mustard, nutritive value, fall grazing sheep

Abbreviations: dry matter (DM), total digestible nutrients (TDN), digestible energy (DE), metabolisable energy (ME), net energy for maintenance $\left(\mathrm{NE}_{\mathrm{m}}\right)$

\section{Introduction}

Fast-growing cold-tolerant brassicaceous plants grown as a second-crop can provide good fall pastures for grazing sheep. Such as are, for example, oil radish (Raphanus sativus L. var. oleiferus) and white mustard (Sinapis alba L.). Planted into cereals' stubble in early-August, both are ready to graze by sheep, goats or games from mid-September under conditions of Hungary (Antal, 2005). The catch crops play an important role in the improving the soil fertilising as green manure. These crops improve the soil's water retaining capacity (Stivers-Young, 1998) and structure (Unger and Vigil, 1998).

In spite of a long history of usage, little information is available on the feed value of oil radish and white mustard, average value of dry matter and crude protein was 130-160 $\mathrm{g} / \mathrm{kg}$ forage and $120-150 \mathrm{~g} / \mathrm{kg}$ dry matter (DM) for oil radish as well as $140-160 \mathrm{~g} / \mathrm{kg}$ forage and $180-200 \mathrm{~g} / \mathrm{kg}$ DM for white mustard, the digestibility of crude protein and fibre was $69-65 \%$ and $70-54 \%$ for oil radish and white mustard (Kakuk and Schmidt, 1988; Schmidt et al., 2000). Moreover, even less on their in situ grazability by sheep
(Antal et al., 1976; Antal, 2005; McLean, 2007). To date, no comparative feeding or grazing trials have been carried out with these two annuals by sheep. Forage nutritive value is a function of the feed intake and the efficiency of extraction of nutrients from the feed during digestion and the feed intake is affected by the amount of forage available, composition of forages (fibre, protein and minerals in the $\mathrm{DM}$ ), feeding frequency, the animal's gut capacity and the passage of undigested DM through the animal (Adesogan $e t$ al., 1993).

In recent times, interest in the use of second crops as green manure has grown Europe-wide. This has prompted us to evaluate the potential of oil radish and white mustard as fall grazing pasture for sheep in the frame of a green manure study.

\section{Materials and methods}

A feeding and a grazing trial were conducted with German Mutton Merino sheep at the Experimental farm of the Szent István University, Gödöllő, Hungary in fall 2009 
and 2010

The oil radish (Raphanus sativus L. var. oleiferus) and white mustard (Sinapis alba L.) without fertiliser were grown at the Crop Production and Biomass Utilisation Demonstration Centre of the Szent István University, Gödöllö, Hungary for animal feeding in 2009 and 2010. The experiments with green plants grown as secondary crops were used. The forage crops used were oil radish and white mustard being in the bloom stage, grown on 0.5 ha plots each.

In the feeding trial (2009), 10 wether lambs (about 9 months old; initial body weight $35.6 \mathrm{~kg}$ ) were used. They were housed in separate barn and received daily $2 \mathrm{~kg}$ meadow hay per head for 7 days before the trial began. Lambs were then kept in individual metabolism crates. Five being fed whole shoots of either forage, mown by hand ca. 5 $\mathrm{cm}$ above ground level. Periods included 7 days for adaptation to forages, followed by 7 days of digestibility trial while $10 \mathrm{~kg}$ per forage were provided. The daily feed allotment in both periods was given in two equal meals at 8 am and 4 pm for 2 hours allowing refusals no higher than $20 \%$. Drinking water, salt blocks were available at all times. Orts were collected; weighted and daily intakes were recorded per animal. Faeces samples were collected by lamb at 24-hr intervals over the last 5 days, and composite samples (50 g) were prepared and stored frozen until analysed. Fresh forage and faecal samples were analysed for dry matter, crude protein $(\mathrm{N} \times 6.25)$, crude fibre, ether extracts and ash according to Weender analysis; the digestibility of crude nutrients was estimated by the indicator method hydrochloric acid insoluble ash (Hungarian Feed Codex, 2004). Total digestible nutrients (TDN), digestible energy (DE), metabolisable energy (ME) and net energy for maintenance $\left(\mathrm{NE}_{\mathrm{m}}\right)$ were calculated (Schmidt et al., 2000).

In the grazing trial (2010), 15 dry ewes were allocated to graze either forage stand in situ. No concentrate supplement was given except salt licks. Drinking water was available at all times. Animals were gradually introduced to forage: 1-2 hrs per day initially and building up unrestricted access in 5 days. White mustard and oil radish pastures were rotationally grazed for 4 days using electric fences. Ewes were allowed 12 hrs of grazing from 8 am to $8 \mathrm{pm}$ and kept overnight in a shed nearby the plots. Daily feeding allocation was calculated for a $50 \mathrm{~kg}$ dry ewe on the basis of the average maintenance requirement (DM: 850-1150 g; $\mathrm{NE}_{\mathrm{m}} 5.82 \mathrm{MJ} \mathrm{kg} \mathrm{DM}$ ), equal to $1 \mathrm{~kg}$ of pasture dry weight (herbage mass) of average quality. Herbage DM yield was estimated by the clipping method using a $2 \mathrm{~m}$ square frame. Five random samples were taken $(3 \mathrm{~cm}$ above ground) from each plot. The fresh weight per $\mathrm{m}^{2}$ was multiplied by 10,000 , then multiplied by the expected crop DM percentage to estimate DM yields per ha. Crop residuals were cut, weighted and DM yields calculated per ha as before. Paddock size was calculated by the pre-grazing herbage mass per $\mathrm{m}^{2}$ and the forage DM requirement of the flock. Ewe carrying capacity of pastures was calculated by the formula given below:

Carrying capacity $(\mathrm{hd} / \mathrm{ha})=[$ Pre-grazing DM yield Post-grazing DM yield (kg/ha)] / DM required $(\mathrm{kg} / \mathrm{hd})$
All variables were subjected to analysis of variance (ANOVA) using the statistical package of SPSS 14.0. Means were compared by F-test and Student's t-test. Differences were considered significant with $\mathrm{P}<0.05$.

\section{Results and discussions}

Forage quality varies considerably with the plant species/genotype, maturity, season, and the growing conditions. Accordingly, the two brassicaceous species (of similar maturity and grown at the same site) differed to some extent in compositional quality (Tab. 1).

Tab. 1. Nutrient composition of the two forage crops fed to wether lambs

\begin{tabular}{lcc}
\hline \multicolumn{1}{c}{ Item } & Oil radish & $\begin{array}{c}\text { White } \\
\text { mustard }\end{array}$ \\
\hline Dry matter $(\mathrm{g} / \mathrm{kg}$ fresh forage $)$ & 135 & 154 \\
Per kg DM & & \\
Crude protein $(\mathrm{g})$ & 148 & 206 \\
Ether extract $(\mathrm{g})$ & 31 & 29 \\
Crude fibre $(\mathrm{g})$ & 141 & 194 \\
Ash $(\mathrm{g})$ & 130 & 89 \\
Nitrogen-free extracts $(\mathrm{g})$ & 550 & 482 \\
\hline
\end{tabular}

White mustard and oil radish composition values are concordance with previous data (Kakuk and Schmidt, 1988; Schmidt et al., 2000). White mustard was higher in dry matter, crude protein and crude fibre but lower in ash and $\mathrm{N}$-freeextracts relative to oil radish. The difference in DM and crude fibre content might be related to a lower leaf/stem ratio present in mustard than radish.

In the feeding trial (Tab. 2), wether lambs consumed per head oil radish or white mustard shoots nearly in the same daily amounts (7.9-7.8 kg); their total DM intakes slightly differed (by $140 \mathrm{~g}$ ) per day and per $\mathrm{BW}^{0.75}$ (by $10 \mathrm{~g}$ ), as well as in percent bodyweight (by $0.39 \%)$. It was due partly to the small betweenspecies differences in DM content $(135 \mathrm{~g} / \mathrm{kg}$ forage for oil radish, $154 \mathrm{~g} / \mathrm{kg}$ forage for white mustard).

Tab. 2. Daily intake, digestibility and energy content of the two forage crops fed to wether lambs of lambs

\begin{tabular}{|c|c|c|c|}
\hline Item & $\begin{array}{c}\text { Oil } \\
\text { radish }\end{array}$ & $\begin{array}{c}\text { White } \\
\text { mustard }\end{array}$ & SEM \\
\hline Daily intake (kg) & 7.88 & 7.82 & 0.06 \\
\hline Daily DM intake (g) & $1063.01^{\mathrm{a}}$ & $1203.50^{\mathrm{b}}$ & 24.95 \\
\hline $\mathrm{DM}$ intake / $\mathrm{BW}^{0,75}(\mathrm{~g})$ & $72.95^{a}$ & $82.59^{\mathrm{b}}$ & 1.71 \\
\hline DM intake / BW (\%) & $2.99^{\mathrm{a}}$ & $3.38^{\mathrm{b}}$ & 0.07 \\
\hline Crude protein (\%) & 69 & 70 & 0.76 \\
\hline Crude fat (\%) & $61^{a}$ & $52^{\mathrm{b}}$ & 1.57 \\
\hline Crude fibre (\%) & $63^{\mathrm{a}}$ & $54^{b}$ & 1.69 \\
\hline Nitrogen-free extracts (\%) & 70 & 71 & 1.11 \\
\hline TDN (\% DM) & 61.6 & 62.9 & 6.36 \\
\hline $\mathrm{DE}(\mathrm{MJ} \mathrm{kg} \mathrm{DM})$ & 11.36 & 11.61 & 0.12 \\
\hline $\mathrm{ME}(\mathrm{MJ} \mathrm{kg} \mathrm{DM})$ & 9.32 & 9.52 & 0.10 \\
\hline $\mathrm{NE}_{\mathrm{m}}(\mathrm{MJ} \mathrm{kg} \mathrm{DM})$ & 5.70 & 5.88 & 0.09 \\
\hline
\end{tabular}

${ }^{\mathrm{ab}}=\mathrm{P}<0.05$ - different letters in a row denote significant differences

Both forage species proved fairly digestible in lambs. Values of investigated parameters are within the ranges for ruminants reported by authors (Kakuk and Schmidt, 1988; 
288

Schmidt et al., 2000). The digestibility coefficients for crude protein and $\mathrm{N}$-free extracts were similar, but the values for crude fibre and crude fat in white mustard significantly $(\mathrm{P}<0.05)$ lower compared with oil radish, respectively.

In the grazing trial, the two ewe flocks consumed voluntarily the test forages in different amounts due to different preference for the plant parts (Tab.3).

Tab. 3. Daily feed allocation and carrying capacity of the two forage crops for ewes

\begin{tabular}{lcc}
\hline \multicolumn{1}{c}{ Item } & $\begin{array}{c}\text { Oil } \\
\text { radish }\end{array}$ & $\begin{array}{c}\text { White } \\
\text { mustard }\end{array}$ \\
\hline Number of ewes & 15 & 15 \\
Daily forage DM requirement $(\mathrm{kg} / \mathrm{ewe})$ & 1.0 & 1.0 \\
$\begin{array}{l}\text { Total DM requirement for } 15 \text { ewes for } 4 \text { days } \\
(\mathrm{kg})\end{array}$ & 60 & 60 \\
Estimated herbage DM yield $\left(\mathrm{kg} / \mathrm{m}^{2}\right)$ & 0.236 & 0.180 \\
Total grazing area required $\left(\mathrm{m}^{2}\right)$ & 254 & 333 \\
Paddock size required $\left(\mathrm{m}^{2} / \mathrm{day}\right)$ & 63 & 83 \\
Pre-grazing DM yield $(\mathrm{kg} / \mathrm{ha})$ & 2360 & 1800 \\
Utilised DM yield $(\%)$ & 72 & 41 \\
Carrying capacity $(\mathrm{ewes} / \mathrm{ha})$ & 1700 & 740 \\
\hline
\end{tabular}

Notably, one utilised $72 \%$ of the oil radish biomass without preference for leaves over stems, whereas the other utilised $41 \%$ of the white mustard biomass leaving the stems nibbled off the leaves. As a general rule, grazing animals usually prefer the younger plants and leaves rather than the stems. Their first preference is new green leaves, if not present, they will choice older green leaves, followed by green stems, then dry leaves, and finally dry stems (Vallentine, 2001). Sheep in previous trials grazed down the entire above-ground biomass of oil radish without trampling loss, when they were herded on the radish stand from the nearby pasture for $1 \mathrm{hr}$ am and $1 \mathrm{hr} \mathrm{pm}$ (Antal et al., 1976). Lower voluntary intakes of forage crops at DM contents above $12 \%$ may reflect the animal's difficulty in harvesting the crops in situ (Barry et al., 1971). In the present trial, the estimated herbage DM content was $\approx 12 \%$ for oil radish and $\approx 16 \%$ for white mustard.

For a grazing situation, an average carrying capacity of a good Brassica pasture would be around 3830 ewe grazing days per ha. Fodder radish produced reportedly 1588-1974 lamb grazing days per ha (Koch et al., 2002). No data available on the carrying capacity of white mustard grazed by lambs in the U.K. (McLean, 2007). Under rotational grazing in the present trial, oil radish provided a carrying capacity twice as high as white mustard's notably, 1700 vs. 740 ewe grazing days per ha equal to 60 ewes grazing one hectare for 28 and 12 days, respectively. These results demonstrate that "leafy" oil radish is superior to "stemmy" white mustard to be used as fall grazing pasture for sheep.

\section{Conclusions}

In the two trials reported here each of the plant species were used as forage for the sheep nutrition. In terms of the crude fibre and crude protein digestibility, particularly in terms of the carrying capacity the oil radish was found to be more favourable than white mustard. However in practical grazing situations, sheep on low dry matter content forage crops must have access to a source of roughage (straw, hay) to provide at least $25 \%$ of the daily dry matter ration adequate for maintenance of proper rumen activity.

Based on our results, recommended the oil radish and white mustard plants in the experiment was suitable for use as fall grazing by sheep.

\section{Acknowledgements}

This work was supported by Kutató Kari Kiválósági Támogatás - Research Centre of Excellence - 175864/2013/TUDPOL project.

\section{References}

Adesogan AT, Sollenberger LE, Newman YC, Vendramini JMB (1993). Factors affecting forage quality. SS-AGR-93/AG 161, In: Newman Y (Ed.) Florida Forage Handbook, 1-5.

Antal J, Jenei E, Szántó Iné (1976). Elaboration of cultural practices for oil radish (Raphanus sativus var. oleiferus (in Hungarian). Növénytermelés 25:375-382.

Antal J (2005). Plant-breeding 2 (in Hungarian). Mezögazda Kiadó, Budapest.

Barry NT, Drew KR, Duncan SJ (1971). The digestion, voluntary intake, and utilisation of energy by Romney hoggets fed five winter forage crops. New Zealand Journal of Agricultural Research 14:835-846.

Hungarian Feed Codex (2004). II/2 OMMI, Budapest.

Kakuk T, Schmidt J (1988). Animal nutrition (in Hungarian). Mezőgazdasági Kiadó, Budapest.

Koch DW, Kercher C, Jones R (2002). Fall and winter grazing of Brassicas - a value-added opportunity for lamb producers. Sheep and Goat Research Journal 17(2):1-13.

McLean B (2007). Alternative forage crops for finishing lambs. ADAS CYMHU Wales Saskatchewan Ministry of Agriculture: Grazing management for sheep production. www.agriculture.gov.sk.ca.

Schmidt J, Várhegyi Jné, Várhegyi J, Túriné CÉ (2000). The evaluation of ruminant feedstuffs for energy and protein content (in Hungarian). Mezőgazda Kiadó, Budapest.

Stivers-Young L (1998). Growth, nitrogen accumulation, and weed suppression by fall cover crops following early harvest of vegetables. Hort Sci 33:60-63.

Unger PE, Vigil MF (1998). Cover crops effects on soil water relationships. J Soil Water Conserv 53(3):200-207.

Vallentine JF (2001). Grazing Management. $2^{\text {nd }}$ Edition. Academic Press, London. 